\title{
A proposed leadership skills development model for African FMCG business-networks: Super-Cube ${ }^{\circledR}$
}

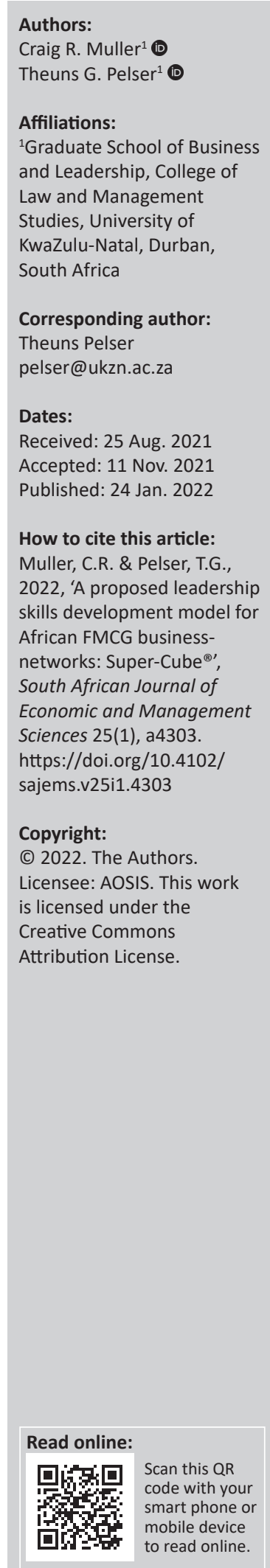

Background: Predictions suggest Africa's combined Gross Domestic Product (GDP) will be amongst the fastest growing on earth in the next two decades. An expectation is that the majority of African homes will enter the consumer class, and educational performance will improve significantly within the next two decades. Nonetheless, organisations competing in Africa face numerous challenges. These include its size and complexity, transformational population growth, an abundance of talent but a lack of skills, a scarcity of large companies, the relatively small size of big companies, a poorly understood business environment, conflict, poverty and corruption. To successfully address these challenges, entrepreneurial energy and a strategy to develop leadership skills at scale is required.

Aim: The purpose of this study was to develop and assess whether a leadership skills development model which integrates six conceptual constructs is valid as a model for developing leadership skills in African fast-moving consumer goods (FMCG) businessnetworks.

Method: The study took a pragmatic approach and followed an explanatory sequential design typology. An initial quantitative stage was conducted. Using inductive thematic interpretation methodology, the qualitative results helped explain the initial quantitative results. Applying confirmatory factor analysis, three data-model fit tests gave empirical evidence that the leadership skills development model was a good model fit.

Findings: The outcomes and practical value of this study included a theoretically relevant, empirically validated leadership skills development model, Super-Cube ${ }^{\circledast}$ for African FMCG (Fast Moving Consumer Goods) business-networks, as well as a range of recommendations on how to develop leadership skills throughout Africa.

Conclusion: Leadership skills development is complex, especially in a rapidly changing environment. This study is the first that proposes a leadership skills development model for African FMCG business-networks that directly contributes to the discipline of leadership and leadership development.

Keywords: leadership; leadership skills; skills development; model; Africa; FMCG; business network; supply chain.

\section{Introduction}

Optimism about Africa's prospects remains widespread and decisive throughout the region (Chironga, Desvaux \& Leke 2018). Africa offers significant opportunities for development to global and local businesses. However, with the continent's complexities, success is not certain: considered strategies are required to transform Africa's future growth opportunities into beneficial and sustainable organisations. Such plans must comprise a thorough approach to its geographical mark, novelty to tackle Africans' unmet requirements, the development of solutions that create resilience in business operations and taking confident and innovative moves to develop the necessary leadership skills amongst local talent.

Given the continent's growing population and Gross Domestic Product (GDP), Africa is likely to become the most potent territory for several industries, particularly the Fast Moving Consumer Goods (FMCG) industry, including packaged food, consumer electronics, beauty and personal care (Leke, Chironga \& Desvaux 2018). The FMCG industry is a strategically important contributor to economic growth (Jacobs \& Mafini 2019). Africa's consumer spending will exceed the global average in the years to come. Most of the increase in Africa's consumer expenditure will come from rapidly growing smaller markets, such as Ethiopia and Kenya, which are both expected to record a consumer spending compound annual growth rate (CAGRs) of 8\% over the 2017-2030 forecast period. 
The lack of big businesses in Africa is not solely a problem for shareholders, but predominately for society, as these organisations are catalysts for economic growth. Big companies are like baobab trees: they tower above others, have deep roots, and have a longer life expectancy. Generally considered, the tree of life, the baobab creates healthy food that maintains several areas. Organisational baobabs promote local industry: they provide financial resources for wages and taxes, operational improvements, innovation, and the adoption of technological advancements. Similar to baobabs, big organisations create ecosystems, promoting smallbusiness creation throughout their supply chain. These large firms are generally better positioned to attract investment, helping them to compete globally. Africa has space, the need, and a growing population to nurture billion-dollar companies across the continent (Leke et al. 2018).

'Africa Rising' refers to a rising middle class, although a vast opportunity still exists at the 'bottom of the pyramid' (BOP) (Euromonitor International 2018:7). The BOP refers to households with an annual disposable income of USD2500 or less (Euromonitor International 2018). The BOP represented more than a third of Sub-Saharan African (SSA) households in 2017, and in South Africa, BOP discretionary expenditure is the highest in the region and will likely increase to $46 \%$ by 2030 (Euromonitor International 2018).

Fast-moving consumer goods products such as food and beverages account for the largest share of BOP households' expenditure across the African continent. However, many of the products purchased are from informal, open-air markets. Reaching these markets requires creative distribution strategies from FMCG businesses. In Africa, partnering with established brands is generally the best way to expand market presence; and gaining access to BOP consumers in Africa usually requires an unconventional distribution network. However, the FMCG industry offers excellent potential (Euromonitor International 2018).

The overarching challenge faced by organisations in the African FMCG industry is to innovate their business model and develop skills to build sustainable and resilient businesses. Africa comprises consumers whose economic activity is greater than India's and will soon have twice the number of smartphone users as North America (Leke et al. 2018).

Capitalising on opportunities offered by both the BOP and the growing middle-class consumer bases will be critical in African countries with bespoke product and service offerings for each segment. Companies will require an in-depth understanding of Africa's diverse consumer profiles to be able to offer products and services to local, regional and countryspecific preferences. Growth in modern retailing requires a business to understand the distribution model and consumer preferences for informal retailing, which is likely to remain dominant for some time (Euromonitor International 2018).

Although poverty in Africa remains prevalent, by reassigning challenges as an invitation for innovation, organisational leadership can help their businesses and Africa to prosper (Euromonitor International 2018; Leke et al. 2018; Swaniker 2018).

Leadership is likely the most critical yet complex challenge facing humanity. Although widely discussed, there is a distinct lack of consent regarding the evolving concept of leadership (Eberly et al. 2013; Landis, Hill \& Harvey 2014). Despite significant investment, a growing concern for organisations is that leadership development initiatives are not building the necessary leadership skills (Cohen 2019; Cullen-Lester, Maupin \& Carter 2017; Eberly et al. 2013).

Cohen (2019) states that the prevailing logic behind leadership programmes appear to be drawn from questionable assumptions, unlike established disciplines such as philosophy, economics and sociology (Burns, Diamond-Vaught \& Bauman 2015; Cohen 2019; Eberly et al. 2013). Dansereau et al. (2013) suggests that an opportunity exists in unifying traditional and contemporary leadership theories. Cullen-Lester et al. (2017) recommends a need for interventions that employ collaborative, multi-level techniques as an approach to increase leadership capacity in organisations. Bolden, Witzel and Linacre (2016) suggest the adoption of interconnected, interdependent, synergistic, holistic, and globalised perspectives in turbulent times. These studies indicate research gaps, needs and opportunities for the integration of leadership theories in which concepts, models and principles unify into a more coherent, holistic, theoretically relevant and empirically validated model (Cullen-Lester et al. 2017; Dansereau et al. 2013; Eberly et al. 2013; Heath, Martin \& Shahisaman 2017; Kim \& McLean 2015; Shrivastava et al. 2014).

Holt, Hall and Gilley (2018) suggest that leaders should be at all levels of an organisation and that everyone contributes towards organisational performance. For an organisation to remain competitive and thus sustainable, organisations need to ensure that leadership skills development initiatives are coherent and provide a multifaceted effort to respond to ongoing internal and external challenges. As such, it seems reasonable to suggest that a gap exists to unify traditional and contemporary leadership theories which employ collaborative, multi-level techniques to increase leadership capacity.

Businesses that succeed in Africa need to invest in talent, and that investment will reap significant rewards for them as they grow. Developing talent is a strategic role, which should be considered part of the value chain and not outsourced to the national university system. Africa has an abundance of talent. Converting this raw talent may only require a short training program that could be enough to unlock the skills that businesses need. Notably, a company that wants to expand into Africa should have a plan for doing good, while doing well (Chironga, Desvaux \& Leke 2019; Leke et al. 2018; Swaniker 2018). Furthermore, African FMCG businesses need leadership development interventions (Jacobs \& Mafini 2019). Therefore, it seems fair to suggest that a gap exists for 
African FMCG businesses to improve leadership capacity to realise their potential.

To address the leadership challenges and the business prospects in FMCG businesses in Africa, an opportunity to cultivate the next generation of leaders and build the required leadership capability for doing good while doing well in Africa.

Considering the above, research gaps concern:

1. The need for the unification of traditional and contemporary leadership theories into a more coherent approach.

2. The need for African FMCG businesses to improve leadership capacity to realise potential.

As such, the research problem statement is as follows:

Leadership skills development initiatives are built on questionable assumptions (Cohen 2019; Eberly et al. 2013) and are not building the necessary leadership skills to improve the leadership capacity required in African FMCG businesses (Chironga et al. 2019; Cohen 2019; Cullen-Lester et al. 2017; Eberly et al. 2013; Jacobs \& Mafini 2019; Leke et al. 2018).

The study has two major research objectives:

1. Theoretical objectives: conceptual model development (to determine theoretically relevant leadership constructs; theoretically relevant approaches to leadership skills development; and to conceptualise a model for leadership skills development).

2. Practical objectives: conceptual model assessment (to perform a quantitative assessment of the appropriateness of the leadership constructs within a conceptual model for leadership skills development; perform a qualitative assessment of leadership skills and the leadership skills development requirements to critically explore how the conceptual model for leadership skills development could develop leadership skills in the African FMCG sector).

The outcomes and practical value of this study included a theoretically relevant, empirically validated leadership skills development model for African FMCG businessnetworks, as well as a range of recommendations on how to develop leadership skills throughout Africa. Leadership skills development is complex, especially in a rapidly changing environment. This study is the first that proposes a leadership skills development model for African FMCG business-networks which directly contribute to the discipline of leadership and leadership development.

The remainder of this article is organised as follows: a review of the applicable literature, developing the conceptual model, a summary of the method followed and the rationale for using an explanatory sequential mixedmethods approach in this study. Then the findings are discussed followed by the conclusion and ideas for further research.

\section{Literature review}

Leadership research extends throughout the behavioural, social, and physical sciences, management, the disciplines of psychology, anthropology, politics, sociology, biology, along with evolutionary studies. In contrast to the comparatively large account of leadership theory and research, the orderly analysis of leadership development (generally defined to also include leader development) has a relatively short history. The ancient Egyptian hieroglyphs also portrayed the leader, follower, and leadership (Yammarino 2017).

More than a century of leadership study has resulted in some paradigm shifts and much confusion. On numerous occasions, leadership scholars have grown frustrated with minor theoretical advances and contradicting results. Bennis (1959) stated six decades ago that:

Of all the hazy and confounding areas in social psychology, leadership theory undoubtedly contends for the top nomination

... Probably more has been written, and less is known about leadership than about any other topic in the behavioural sciences. (pp. 259-260)

Equally, Hackman and Wageman (2007) established that the subject of leadership is 'curiously unformed' (p. 43). For the last half-century, leadership scholars have battled to construct an integrated and theoretically cohesive view of leadership. As such, leadership remains an expansive and essential field of study (Bass \& Bass 2008; Day et al. 2014; Day \& Thornton 2018; Yammarino 2017; Yukl 2012).

Leadership is central in the managerial and mainstream media world. Corporate, government, military, and not-forprofit organisations all require the development of effective leadership, which is currently a major concern for all kinds of organisations (Day et al. 2014). Despite significant growth and investment in leadership development, there is little proof that leadership is improving and being more effective. Leaders at the wheel of various religious, financial, corporate, educational, and government institutes have been responsible for huge failures that eroded public trust and have damaging social, economic, political and environmental consequences (Cohen 2019). To find solutions to the complex problems faced by our global society, we need leaders who have the necessary skills to transform our current social, economic, political and ecological realities (Burns et al. 2015).

Leadership is possibly the most critical event in the field of human behaviour, as almost nothing gets done without it. Leadership is also one of the social sciences most significant studied phenomena, in which the scrutiny afforded is, not surprisingly, taking into consideration that it is a widespread action marked in both humanity and the animal species (Bass \& Bass 2008). Reference to leadership is evident in Western and Eastern texts, with a general consensus that leadership is essential for social, economic and environmental development (Antonakis \& Day 2018; Yammarino 2017).

While leadership may be simple to recognise in practice, it is often hard to define. Considering the multifaceted study of 
leadership, a generally agreed definition of leadership does not presently exist. Also, Antonakis and Day (2018) points out that learnings in the social sciences remain not cohesively integrated, and the perspective that leadership researchers operate from, is uncertain. Fiedler (1971) notes: 'There are as many definitions of leadership as there are leadership theories - and there are almost as many theories of leadership as there are psychologists working in the field' (p. 1). It is, therefore, problematic to get leadership researchers to settle on a definition. In the absence of consensus, the following description of leadership is made by Antonakis and Day (2018):

Leadership is a formal or informal contextually rooted and goalinfluencing process that occurs between a leader and a follower, groups of followers, or institutions. The science of leadership is the systematic study of this process and its outcomes, as well as how this process depends on the leader's traits and behaviors, observer inferences about the leader's characteristics, and observer attributions made regarding the outcomes of the entity led.

\section{Leadership dimensions, attributes, and constructs}

Following the establishment of theoretically relevant leadership dimensions and attributes, six constructs were conceptualised. The six leadership constructs are choices, principles, mental (cognitive), emotional, physical, and spiritual, which are perceived as humancentric, multidimensional and inherently incorporate the notion of being developmental, that is, they can be developed. Table 1 provides a summary of the six leadership constructs, the associated construct theories, as well as examples of the related leadership skills for development.

\section{A conceptual leadership model}

The researchers conceptualised a six-construct leadership model from the leadership theory discussed and presented previously. The conceptual leadership model was represented as a cube and named Super-Cube ${ }^{\circledR}$. The Super-Cube ${ }^{\circledR}$ model implies that each side of the cube integrates to create a holistic, coherent, multifaceted, human-centric perspective.

Foti and Hauenstein (2007) argue that the person is considered as an integrated totality rather than a summation of variables' (p. 347). Leadership scholars argue that progressing research on traits or personal characteristics and their effects on leadership require more multifaceted models and approaches (Bass 1990; Lord \& Hall 1992; Zaccaro, LaPort \& Jose 2012). Taking the above into consideration, the researchers conceptually developed a leadership model which comprised six leadership constructs grounded in academic literature.

In the conceptualisation and naming of the conceptual model, the word cube refers to 'you', where the letter ' $u$ ' in the word cube represents you - a leader. The word super is an adjective, in which case it implies you are wonderful, fantastic, great, marvellous, fabulous, excellent, splendid, superb, brilliant, superior, enhanced, and outstanding, etcetera. The objective
TABLE 1: Leadership constructs, associated theories, and skills.

\begin{tabular}{|c|c|c|}
\hline Leadership constructs & $\begin{array}{l}\text { Theory, author(s) and a } \\
\text { brief description or } \\
\text { explanation }\end{array}$ & $\begin{array}{l}\text { Leadership skills for } \\
\text { development }\end{array}$ \\
\hline $\begin{array}{l}\text { (1) Choices (e.g. morals, } \\
\text { values, attitude, } \\
\text { decision-making, } \\
\text { judgement, risk-taking) }\end{array}$ & $\begin{array}{l}\text { Choice theory: Levin and } \\
\text { Milgrom (2004). } \\
\text { Choice theory is the skilful } \\
\text { process of evaluating } \\
\text { available options and then } \\
\text { choosing the preferred } \\
\text { option based on a } \\
\text { consistent criterion. }\end{array}$ & $\begin{array}{l}\text { E.g. Decision-making; risk } \\
\text { assessment; moral } \\
\text { decision-making }\end{array}$ \\
\hline $\begin{array}{l}\text { (2) Principles (e.g. ethics, } \\
\text { context, situation, } \\
\text { principles) }\end{array}$ & $\begin{array}{l}\text { Principle theory: Caldwell } \\
\text { et al. (2006). } \\
\text { Principle theory provides } \\
\text { a foundation of guiding } \\
\text { principles which relate to } \\
\text { a person's ability to act by } \\
\text { the rules or standards. }\end{array}$ & $\begin{array}{l}\text { E.g. Context; ethics; } \\
\text { governance }\end{array}$ \\
\hline $\begin{array}{l}\text { (3) Mental (e.g. cognitive, } \\
\text { logos, problem-solving, } \\
\text { knowledge, experience, } \\
\text { understanding, memory, } \\
\text { education, goals) }\end{array}$ & $\begin{array}{l}\text { Cognition theory: } \\
\text { Prinsloo and Barrett (2013), } \\
\text { Mumford et al. (2017). } \\
\text { Cognition theory is a } \\
\text { person's ability to solve } \\
\text { problems, to plan, to reason, } \\
\text { to think conceptually, to } \\
\text { grasp complex concepts } \\
\text { and to learn quickly, as well } \\
\text { as learn from experience; } \\
\text { cognitive skills are essential } \\
\text { aspects and of critical } \\
\text { importance in the } \\
\text { leadership context. }\end{array}$ & $\begin{array}{l}\text { E.g. Thinking; learning; } \\
\text { teaching }\end{array}$ \\
\hline $\begin{array}{l}\text { (4) Emotional (e.g. } \\
\text { emotion, pathos, social, } \\
\text { motives, self-efficacy, } \\
\text { relational, communication, } \\
\text { social, interpersonal, } \\
\text { influence, conflict } \\
\text { resolution) }\end{array}$ & $\begin{array}{l}\text { Emotional intelligence } \\
\text { theory: Doe et al. (2015), } \\
\text { Heath et al. (2017); Mayer } \\
\text { et al. (2004). } \\
\text { Emotional intelligence } \\
\text { theory comprises a } \\
\text { four-branch ability model } \\
\text { of a person being able to } \\
\text { perceive, use, understand } \\
\text { and manage emotions. } \\
\text { Each branch of emotional } \\
\text { intelligence can be } \\
\text { developed and are vital } \\
\text { attributes of effective } \\
\text { leadership. }\end{array}$ & $\begin{array}{l}\text { E.g. Social skills; } \\
\text { motivation; self-awareness }\end{array}$ \\
\hline $\begin{array}{l}\text { (5) Physical (e.g. physical, } \\
\text { stress, body, physiological) }\end{array}$ & $\begin{array}{l}\text { Physical wellbeing theory: } \\
\text { Hattie et al. (2004). } \\
\text { The 'Wheel of Wellness' } \\
\text { theory relates to a person's } \\
\text { physical health, and that } \\
\text { stress management, } \\
\text { nutrition, and exercise are } \\
\text { critical aspects of the } \\
\text { physiological wellbeing of } \\
\text { a leader. }\end{array}$ & $\begin{array}{l}\text { E.g. Stress management; } \\
\text { nutrition; exercise }\end{array}$ \\
\hline $\begin{array}{l}\text { (6) Spiritual (e.g. character, } \\
\text { ethos, integrity, trust, } \\
\text { purpose, trust-building, } \\
\text { role-model) }\end{array}$ & $\begin{array}{l}\text { Spirituality Scale: Avolio } \\
\text { (2007), Delaney (2005); } \\
\text { Maslow (1972). } \\
\text { The 'Spirituality Scale' is a } \\
\text { method to assess a person's } \\
\text { beliefs, values, and choices. } \\
\text { The spiritual life (the } \\
\text { contemplative, religious, } \\
\text { philo-sophical) is part of the } \\
\text { essence of a human being, } \\
\text { a defining characteristic. }\end{array}$ & $\begin{array}{l}\text { E.g. Individual, team, and } \\
\text { organisational leadership } \\
\text { (purpose, meaning, and } \\
\text { values) }\end{array}$ \\
\hline
\end{tabular}

is to provide a model that promotes and enables superior leadership (you) capability, that is you (from a multidimensional perspective) are super.

The conceptual model proposes Buber's I-Thou relation, which appreciates people as equals (Morgan \& Guilherme 2012). The I-Thou relation highlights the mutual and holistic existence of two entities. Morgan and Guilherme (2012) describe the I-Thou approach as an encounter of equals who value each other as such. The ethical nature of the I-Thou relation suggests that if someone is unable to respect fellow human beings as persons and see them merely as objects, that person, too, will be considered an object (Morgan \& Guilherme 2012). This approach represents a person as a 
means to an end, which ceases to ascribe rights and duties to both parties. However, Buber encouraged people and communities to see fellow human beings as Thous, with the same psychological, intellectual, emotional, and spiritual attributes. In this study, the conceptual model appreciates people as holistic entities, comprising multidimensional capabilities, capable of being both leaders and/or followers in certain contexts.

The first two theories of the conceptual leadership model represent the choices and principles constructs. Choice theory is the notion that making choices is a process of evaluating available options, requiring multiple skills, and then choosing the preferred option based on a consistent criterion (Levin \& Milgrom 2004). Levin and Milgrom (2004) suggest that realworld choices often appear to be highly situational and context-dependent, such as the social context, the emotional state of the decision-maker, and a variety of other environmental factors which influence choice behaviour. From the conceptual model perspective, the choice construct represents the primary function, influenced by the cognitive, emotional, physical, and spiritual dimensions, yet conceptually guided by the principles construct.

Principle theory provides a foundation of guiding principles that relate to a person's ability to act by the rules or standards (Caldwell, Karri \& Vollmar 2006). Furthermore, Johns (2006) suggests that context is a phenomenon external to the individual, yet it affects leadership decision-making. In the context of this study, the principle construct represents the rules and standards of social, economic, and natural laws, e.g. science, technology, engineering, and mathematics (STEM). In essence, the principles construct represents ethics (decision-making foundations) and, thus, ethical leadership development for the greater good of humanity (Wilson \& McCalman 2017). Based on the principles in these two theories, it seems reasonable to suggest that choice and principle theory support and guide one another as established in the conceptual model for leadership skills development.

The following four theories represent the remaining (cognitive, emotional, physical, and spiritual) constructs of the conceptual leadership model.

Concerning the conceptual leadership model, the cognitive construct represents a leader's mental intelligence. Cognition faculties refer to a person's knowledge, skills, and ability to solve problems, to plan, to reason, to think conceptually, to grasp complex concepts, and to learn quickly, as well as learn from experience, and the ability to teach; these cognitive skills are essential aspects of critical importance within and throughout the leadership context (Mumford et al. 2017; Prinsloo \& Barrett 2013). Mumford et al. (2017) argue that mental intelligence ultimately refers to the speed and depth of leaders' information processing skills and abilities when working to solve complex problems. Furthermore, evidence suggests that mental intelligence can be developed to provide people with the knowledge and skills they need to perform complex leadership tasks (Mumford et al. 2017).
Emotional intelligence theory comprises of a four-branch ability model of a person being able to perceive, use, understand and manage emotions (Mayer, Salovey \& Caruso 2004). Each branch of emotional intelligence can be developed and is a critical aspect of effective leadership (Doe, Ndinguri \& Phipps 2015; Mayer et al. 2004). Heath et al. (2017) state that great leaders can develop the following five emotional intelligence skills: namely, self-awareness, self-regulation, motivation, empathy, and social skills. The first three skills are considered part of personal competence, while the last two skills are considered social competence, all of which determine how leaders handle relationships (Doe et al. 2015).

The physical construct of the conceptual model for leadership skills development represents a leader's physiological wellbeing and is conceptualised as physical intelligence. The 'Wheel of Wellness' theory concerns a person's physical health and the fact that stress management, nutrition, and exercise are all vital aspects of the physiological well-being of a leader (Hattie, Myers \& Sweeney 2004). Harms et al. (2017) suggest that stress and leadership are inextricably linked to one another and argue that stressful events especially require good leadership. Leaders who can handle stressful events effectively are generally more inclined to good decision-making and group fitness (Harms et al. 2017). Edwards (2006) maintains that regular exercise for an average of $30 \mathrm{~min}$ a day, at least three times a week, is associated with significant improvements in a person's physical well-being, as well as aspects of mood, coherence, fortitude, and stress management.

The spiritual construct of the conceptual model for leadership skills development conceptually represents the conduit between the leader's choice construct and the principle construct. The construct also symbolises the fusion between the mental, emotional, and physical aptitude of a leader. Delaney's (2005) 'Spirituality Scale' is a method used to assess a person's beliefs, values and choices. Maslow (1972) contends that 'the spiritual life (the contemplative, religious, philosophical, or value-life) is ... part of the human essence ... a defining characteristic of human nature ...'. Avolio (2007) suggests that spiritual intelligence is central in leadership as it unites the four innate aspects of a person's existence (mind, heart, body and spirit), so that people are who intrinsically motivated to achieve important goals, are more committed to achieving organisational objectives and experience higher levels of personal joy, peace and fulfilment. Research findings in South Africa established that higher levels of spirituality were generally associated with improved health, fewer mental health problems, and better healthrelated physical, psychological and environmental aspects of life outcomes (Edwards 2012).

Based on the conceptual leadership model, the researchers define:

Leadership is a multidimensional, human-centric and principled approach towards the progression of humanity. 


\section{A conceptual leadership skills development model}

The above section discussed the topic of leadership and presented a six-construct conceptual leadership model. This section provides a review of leadership development literature towards the conceptualisation of a leadership skills development model.

Researchers suggest that leadership development is inherently a multi-level process (Avolio 2007; Day \& Dragoni 2015). There are within-person and between-person levels; higher dyadic levels involving relationships with followers, peers, and subordinates; and team and organisational levels. It appears that cross-level research approaches will further the understanding of leadership skills development.

Leading and leadership development is a dynamic and longitudinal process, which involves the consideration of time (Day 2014). The development of organisational leadership in general, and leaders, in particular, is a process occurring throughout the entire adult lifespan (Day et al. 2012). Furthermore, leaders do not develop all in the same way with identical growth patterns (Day \& Sin 2011). People learn different things from the same experience, and some learn the critical lessons of experience quicker than others (Day \& Thornton 2018).

A notion exists that leaders are ill-prepared to handle future challenges. Drucker (1995) noted that no more than one-third of executives selection decisions turn out right, approximately one-third are marginally useful, and the final one-third outright failures. A concern regarding these estimates is that while leadership development is a strategic human capital issue in many organisations, both current and past data suggest that it is not enough.

One issue that undermines the effectiveness of leadership development initiatives is the focus on generally short-term, episodic-based thinking of how development occurs. Typically, the notion of leadership development has been viewed as a series of unconnected, discrete programmess with minimal assistance in integration across the development episodes (Vicere \& Fulmer 1998). In contemporary views of leadership development, it is considered a continuous and ongoing process throughout the adult lifespan (Day et al. 2012). McCauley et al. (2010) suggest that just about all experience has the potential to enhance learning and development and will likely do so to the extent that it includes aspects of assessment, challenge, and support.

The focus in the field relates to developing individual leader skills, although there is no assurance that improved leadership will result. As such, leadership involves collaboration within a given situational context. Thus, effective followers are required, along with effective leaders (Hollander 2009). Furthermore, real collective leadership development will possibly require intervention at the group, team, or organisational levels.
Despite the distinction between leader development and leadership development, it is not an either/or proposition. Instead, advanced initiatives seek to establish ways to combine individual leader development with collective leadership development to further overall leadership capacity in teams and organisations (Day \& Dragoni 2015).

Table 2 presents the leadership skills development findings from the review of leadership development theory, concepts, terms, definitions, and models from the leadership skills development categories reviewed.

The unification of the conceptual leadership model (discussed and presented in Section 2.2) and the leadership skills development findings in Table 2, a model for leadership skills development was conceptualised as shown in Figure 1.

In the conceptual model for leadership skills development, the leadership skills development process is considered inherent in each of the six leadership constructs in the model.

The leadership skills development rationale follows that (1) leadership can and does develop over time (De Neve et al. 2013); (2) structure programmes and experiences best promote leadership development (Conger 2010; Day \& Thornton 2018; Kegan \& Lahey 2016) ; and (3) it adheres to the theory of learning during the developmental process (Illeris 2018).

Based on the conceptual leadership skills development model, the researchers define leadership skills development:

Inherent skills developed by structured methodologies concerning the learning theory, regarding the development of

TABLE 2: Leadership skills development summary.

\begin{tabular}{|c|c|c|}
\hline $\begin{array}{l}\text { Leadership theory, } \\
\text { concepts and models }\end{array}$ & $\begin{array}{l}\text { Author(s) and a brief } \\
\text { description or explanation }\end{array}$ & $\begin{array}{l}\text { Leadership skills } \\
\text { development }\end{array}$ \\
\hline Nature vs Nurture & $\begin{array}{l}\text { De Neve et al. (2013). } \\
\text { Leadership can be developed } \\
(70 \%-76 \%) \text { with on-going } \\
\text { practise and experience as } \\
\text { opposed to purely inheritable } \\
(24 \%-30 \%) \text {. }\end{array}$ & Practice; experience \\
\hline $\begin{array}{l}\text { Leader development } \\
\text { through time }\end{array}$ & $\begin{array}{l}\text { Day and Thornton (2018); } \\
\text { Gully and Chen (2010). } \\
\text { Individuals do not experience } \\
\text { or benefit from leader } \\
\text { development in the same } \\
\text { ways. Leaders can and do } \\
\text { develop over time. }\end{array}$ & $\begin{array}{l}\text { Personality; psychosocial; } \\
\text { emotional }\end{array}$ \\
\hline $\begin{array}{l}\text { What occurs in leader } \\
\text { development }\end{array}$ & $\begin{array}{l}\text { Day and Thornton (2018); } \\
\text { Hollenbeck, McCall and Silzer } \\
\text { (2006); Mumford, Campion } \\
\text { and Morgeson (2007). } \\
\text { Leadership competencies } \\
\text { such as leadership- related } \\
\text { knowledge, skills and abilities }\end{array}$ & $\begin{array}{l}\text { Cognitive; emotional; } \\
\text { principles; decision- } \\
\text { making }\end{array}$ \\
\hline $\begin{array}{l}\text { How best to promote } \\
\text { leadership development }\end{array}$ & $\begin{array}{l}\text { Conger (2010); Day and } \\
\text { Thornton (2018); Kegan and } \\
\text { Lahey (2016). } \\
\text { Structured programmes, } \\
\text { experiences, and continuous } \\
\text { developmental practices best } \\
\text { promote leadership } \\
\text { development. }\end{array}$ & $\begin{array}{l}\text { Personality; values; } \\
\text { emotion; vision; } \\
\text { principles; cognition. }\end{array}$ \\
\hline Learning theory & $\begin{array}{l}\text { Illeris (2018). } \\
\text { Comprises of three } \\
\text { dimensions, namely content, } \\
\text { incentive, and interaction. }\end{array}$ & $\begin{array}{l}\text { Content (cognitive); } \\
\text { incentive (emotional); } \\
\text { interaction (social). }\end{array}$ \\
\hline
\end{tabular}




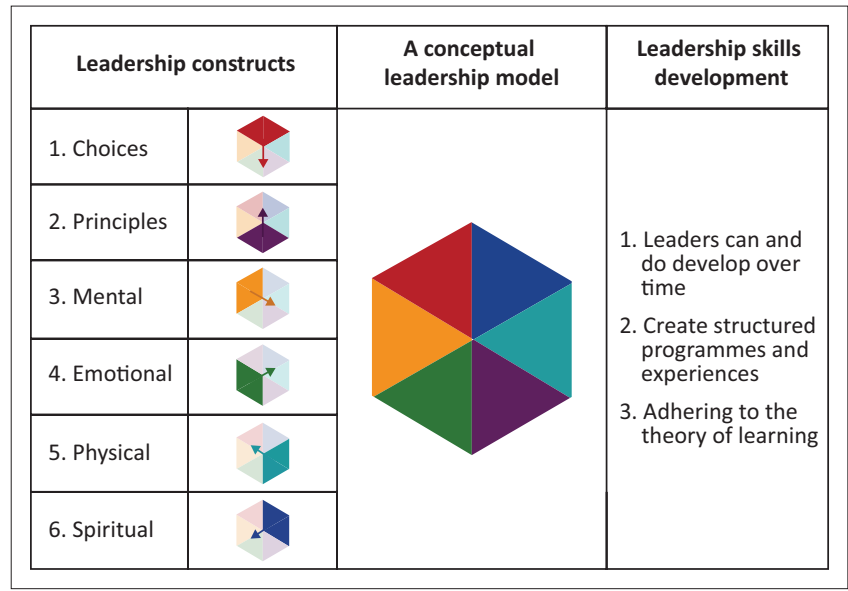

FIGURE 1: A conceptual model for leadership skills development.

multidimensional, human-centric and principled approaches towards the progression of humanity.

The following section reviews the research design and methodology to help address the research questions.

\section{Research design and methodology}

Pragmatism is typically associated with mixed-methods research as an overarching philosophy (Tashakkori \& Teddlie 2003). In studies with a pragmatic worldview, the importance of the research concerns is finding practical results. It is recognised that single perspectives may not provide the solutions, and that there may be multiple realities (Saunders \& Tosey 2012). From a pragmatic worldview, the focus is on research outcomes and the importance of the question asked rather than the methods (Creswell \& Plano Clark 2018).

Due to the complex nature of the research problem addressed in this study, an overarching philosophy of pragmatism has been embraced, as it combines two worldviews that provide the benefit of addressing the research problem from multiple perspectives, that is pragmatism is one philosophy that includes post-positivism and constructivism (McMillan \& Schumacher 2010).

In this study, the researchers used both quantitative and qualitative research methodologies, known as mixed-methods research. In mixed-methods research, three core typologies exist, namely: (1) convergent designs; (2) explanatory sequential designs; and (3) exploratory designs (Creswell \& Plano Clark 2018).

This study required that the qualitative results would further explain the initial quantitative results, regarding the deductive analysis of a conceptual model for leadership skills development. As a result, this study took an explanatory sequential design typology which started by conducting a quantitative stage and following up on the results at a qualitative stage

An in-depth case study was done to develop a leadership skills development model. This was based on a quantitative research method, in which the results were used to assist with further questions during the interviews, as a qualitative research method in an explanatory sequential mixedmethods design.

\section{Quantitative strand}

For the quantitative research, ordinal scales were used to develop response options. Scales were developed to measure, inter alia, the knowledge, beliefs, attitudes, judgements, and sentiments concerning the six constructs of the conceptual leadership skills development model. Terre Blanche and Durrheim (1999) state that a scale measures the intensity, direction and level of potency of the variable being measured. Three questions, relating to each of the six constructs were used as the scales. The questions originated from the leadership theory associated with dimensions and attributes pertaining to each construct in the conceptual model for leadership skills development.

When developing the electronic questionnaire survey, the researchers took the following into account (Cooper \& Emory 1995; Creswell \& Plano Clark 2018; Terre Blanche \& Durrheim 1999):

1. Strengths: The ability to access many participants; an economic process; an ability to ensure anonymity; and the potential to generalise to large populations.

2. Limitations and weaknesses: possible high non-response rate; possible potential misinterpretation of questions; and excluding questions that may have been of value.

Following the conceptualisation and operationalisation of the six constructs in the conceptual model for leadership skills development, the researchers developed a questionnaire survey. The questions aimed to evaluate the constructs of the conceptual model for leadership skills development.

The questionnaire consisted of the following sections:

1. Research project overview;

2. Informed consent; and

3. Leadership question evaluation:

3.1 Choices construct: three questions;

3.2 Principles construct: three questions;

3.3 Mental construct: three questions;

3.4 Emotional construct: three questions;

3.5 Physical construct: three questions; and

3.6 Spiritual construct: three questions.

The questionnaire was subsequently converted into an electronic format (using the online Google Forms application). The electronic questionnaire was designed to ensure each question had to be answered, negating the risk of missing values. Also, as the questionnaire was to be completed anonymously, the risk of bias (if the survey was not anonymous) offset the multiple-submission risk and additionally, participants had no incentive to complete the survey. The last step in the measurement development phase included a pre-test. 
The target population (or unit of analysis) was contextualised within a leading FMCG company that operates exclusively in African countries. The target population was further defined as employees who had a company email address and thus had access to email. An invitation to participate in the research study was emailed to the target population. Over 10 weeks, one hundred thirty-two (132) responses were received, corresponding to a $43.9 \%$ response rate.

Statistical analysis was undertaken by the Statistical Consultation Services of the North-West University using the Statistical Package for the Social Sciences (IBM SPSS/AMOS Statistics Version 25) consisting of descriptive and multivariate techniques. This research followed non-parametric statistical techniques as the focus of the study was on the order and ranking of ordinal scales (distinct and ranked) (Terre Blanche \& Durrheim 1999; Terre Blanche, Durrheim \& Painter 2006). To further address the research problem, validation of the conceptual model for leadership skills development was required. A multivariate Confirmatory Factor Analysis (CFA) technique was followed in this study as a CFA is a theory-testing approach, as opposed to a theory-generating approach (Stapleton 1997). In order to establish the internal consistency reliability of the constructs, Cronbach's alpha coefficients were calculated for each construct as a method of determining the reliability and internal consistency amongst the constructs (Cooper \& Emory 1995; Field 2009).

\section{Qualitative strand}

The primary intent of a mixed-methods explanatory sequential design is for the qualitative phase to explain the initial quantitative results (Creswell \& Plano Clark 2018). The researchers invited 14 'key decision-makers' from the FMCG company to participate in a one-on-one, face-to-face in-depth interview. The term 'key decision-makers' refer to the company directors who are ultimately responsible for leadership in the organisations within the FMCG company and are likely the most informed. The sampling methodology for the qualitative strand of this study was purposeful sampling, by which all 14 'key decision-makers' were invited to participate in the study. Creswell and Plano Clark (2018) propose that a case-study sample size should be between 4 and 10 participants, and in this study, 10 of the 14 key decision-makers were willing and able to participate, which is a response rate of $71.43 \%$.

The data analysis comprised of thematic interpretation and aimed to explore and elaborate on the results from the quantitative results. The validity of the qualitative data was assured by applying the four criteria used to ensure a trustworthy study, namely credibility, transferability, dependability and conformability (Shenton 2004).

The credibility of the findings was secured by triangulating multiple perspectives to interpret a single set of data, as well as that the research findings could be combined on a more analytical macro-level of inference (Groenland \& Dana 2019; Terre Blanche \& Durrheim 1999; Terre Blanche et al. 2006).

\section{Conceptual model-fit}

Terre Blanche and Durrheim (1999) argue that theories are general truth statements that researchers put to the empirical test by deriving hypotheses about observations. The motive for this modelling is that the real world is generally so complex that it typically requires to be conceptually simplified to understand it.

To further address the research problem, validation of the conceptual model for leadership skills development was required.

A multivariate CFA technique was followed in this study as a CFA is a theory-testing approach, as opposed to a theorygenerating approach (Stapleton 1997). In CFA, the researchers begin with a hypotheses or conceptual model, in this case, a conceptual model for leadership skills development, and specifies which variables will be correlated with which factors, and which factors do indeed correlate.

Confirmatory methods, following the specification of the priori factors, seek to optimally match the observed and theoretical factor structures for a given data set in order to determine the 'goodness of fit' of the predetermined factor model (Stapleton 1997:7).

\section{Findings}

The quantitative results of the appropriateness of the leadership constructs in a conceptual model for leadership skills development include the response rate, descriptive statistics of the organisation, construct validity and construct reliability. The online quantitative questionnaire had a $43.9 \%$ response rate. The age group with the highest population is those $36-45$-year old, at $36 \%$ of the population. The second highest age group population is those $25-35$-year old, at $28 \%$. There is a small population of below 25 years old at $4 \%$, and only $1 \%$ at over 65 years old. The gender population is relatively equal; however, there were slightly more female participants at $53 \%$ versus $47 \%$ of the male population. Thirty per cent of the population had an undergraduate qualification, $26 \%$ a postgraduate qualification, $12 \%$ of the population have a secondary qualification, 5\% a certification and 5\% a trade certification. Twenty-two per cent of the population did not indicate their qualification status.

Table 3 shows the online survey questionnaire results. The results present the mean and standard deviation for each of the survey questions. While descriptive statistics results provide information regarding each question, i.e. the mean and standard deviation, this information alone does not provide enough insight into the overall meaningfulness of the constructs in the conceptual model.

Confirmatory factor analysis was used as it provides a viable method for evaluating construct validity (Stapleton 1997). Figure 2 provides a graphical representation of the constructto-construct relationship. 
TABLE 3: Online survey questionnaire results.

\begin{tabular}{|c|c|c|c|c|}
\hline $\begin{array}{l}\text { Question } \\
\text { number }\end{array}$ & Construct & Questions & Mean & $\begin{array}{l}\text { Standard } \\
\text { deviation }\end{array}$ \\
\hline 1 & Choices & $\begin{array}{l}\text { How important is it for a leader to } \\
\text { act morally? }\end{array}$ & 6.80 & 0.670 \\
\hline 2 & Choices & $\begin{array}{l}\text { How important is it for a leader to } \\
\text { manage risk? }\end{array}$ & 6.46 & 0.868 \\
\hline 3 & Choices & $\begin{array}{l}\text { How important is it for a leader to } \\
\text { make moral decisions? }\end{array}$ & 6.72 & 0.724 \\
\hline 4 & Principles & $\begin{array}{l}\text { How important is it for a leader to } \\
\text { communicate and instil company } \\
\text { values in the team? }\end{array}$ & 6.66 & 0.616 \\
\hline 5 & Principles & $\begin{array}{l}\text { How important is it for a leader to } \\
\text { work ethically? }\end{array}$ & 6.83 & 0.413 \\
\hline 6 & Principles & $\begin{array}{l}\text { How important is it for a leader to } \\
\text { ensure the company operates } \\
\text { ethically? }\end{array}$ & 6.78 & 0.484 \\
\hline 7 & Mental & $\begin{array}{l}\text { How important is it for a leader to } \\
\text { have good thinking skills? }\end{array}$ & 6.61 & 0.661 \\
\hline 8 & Mental & $\begin{array}{l}\text { How important is it for a leader to } \\
\text { practise personal reflection? }\end{array}$ & 6.09 & 1.142 \\
\hline 9 & Mental & $\begin{array}{l}\text { How important is it for a leader to } \\
\text { learn something new and teach } \\
\text { and/or demonstrate what they } \\
\text { have learnt? }\end{array}$ & 6.13 & 1.007 \\
\hline 10 & Emotional & $\begin{array}{l}\text { How important is it for a leader to } \\
\text { work with the team, and involve } \\
\text { the right people at the right time? }\end{array}$ & 6.70 & 0.549 \\
\hline 11 & Emotional & $\begin{array}{l}\text { How important is it for a leader to } \\
\text { be motivated and disciplined to } \\
\text { achieve an important goal? }\end{array}$ & 6.75 & 0.468 \\
\hline 12 & Emotional & $\begin{array}{l}\text { How important is it for a leader to } \\
\text { communicate effectively with the } \\
\text { team? }\end{array}$ & 6.87 & 0.336 \\
\hline 13 & Physical & $\begin{array}{l}\text { How important is it for a leader to } \\
\text { consume healthy foods? }\end{array}$ & 5.05 & 1.530 \\
\hline 14 & Physical & $\begin{array}{l}\text { How important is it for a leader to } \\
\text { manage personal and team stress? }\end{array}$ & 6.33 & 0.805 \\
\hline 15 & Physical & $\begin{array}{l}\text { How important is it for a leader to } \\
\text { do some exercise? }\end{array}$ & 5.04 & 1.550 \\
\hline 16 & Spiritual & $\begin{array}{l}\text { How important is it for a leader to } \\
\text { work toward achieving meaning, } \\
\text { purpose and fulfilment in their life? }\end{array}$ & 5.95 & 1.152 \\
\hline 17 & Spiritual & $\begin{array}{l}\text { How important is it for a leader to } \\
\text { lead and serve a team to achieve } \\
\text { company objectives? }\end{array}$ & 6.70 & 0.523 \\
\hline 18 & Spiritual & $\begin{array}{l}\text { How important is it for a leader to } \\
\text { lead a company to achieve the } \\
\text { organisational dream (vision)? }\end{array}$ & 6.66 & 0.640 \\
\hline
\end{tabular}

To determine the relative contribution of each variable, i.e. each question, a standardised regression weight analysis was performed. Table 4 presents the standardised regression weight results.

The results from the standardised regression weights analysis determined the relative contribution of each variable (research question), and in this case, are noted as the estimate. Estimates values between 1.0 and 0.5 are acceptable; however, values of 0.3 are also considered acceptable. The choices construct had an estimate of 1.071, 0.776 and 0.377 . While an estimated value of 1.071 is marginally higher than 1.0 , it is deemed acceptable. The principles construct results of $0.713,0.622$ and 0.529 , are deemed acceptable.

The results for the cognitive construct were 0.710, 0.614 and 0.495 , all considered acceptable. The emotional construct results were $0.804,0.518$ and 0.509 , all deemed acceptable. The results of the physical construct were $0.969,0.955$ and 0.386 , which are all acceptable. The spiritual construct results were $0.773,0.736$ and 0.572 , and all were deemed acceptable. Table 5 shows the constructto-construct correlation results.

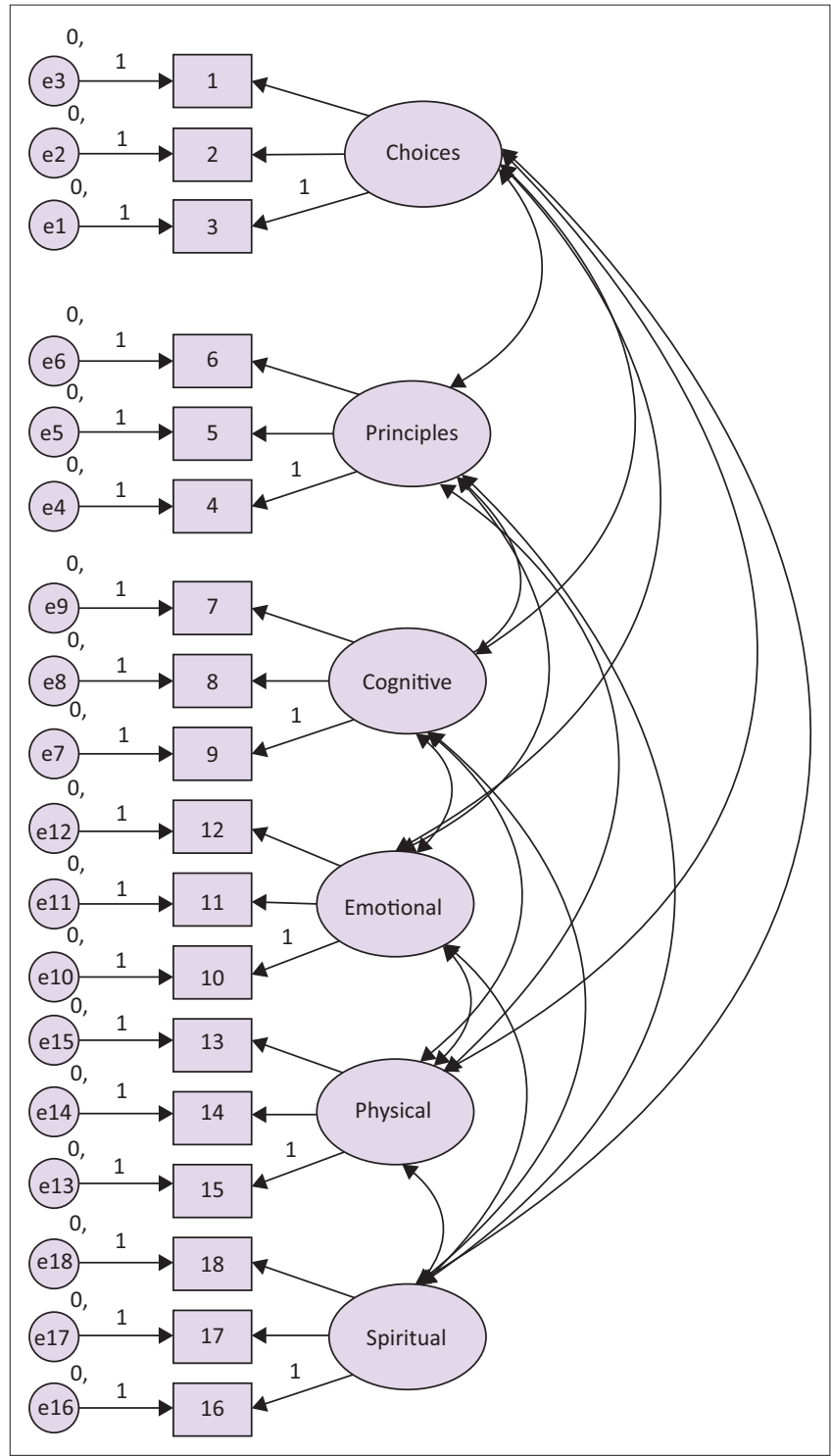

FIGURE 2: Confirmatory factor analysis.

The $p$-value results of the choices and cognitive (0.247), choices and physical (0.481), and spiritual and choices (0.295) reported low construct-to-construct statistical significance correlation. However, the majority (83\%) of the construct-to-construct correlations were statistically significant.

Behr (1983) provides a construct correlation strength description (see Table 6) that the researchers used to interpret the construct-to-construct correlation results.

The highest, near-perfect correlation exists between the mental and emotional constructs. These findings suggest that an almost perfect relationship occurs in participants' perception of leaders' abilities to think, to learn, and their self-awareness, with their ability to perceive, use, understand and manage emotions. In relation to the conceptual model, the mental and emotional constructs are presented as being side-by-side, both acting as conduits between the choices and principles constructs. 
TABLE 4: Standardised regression weight results.

\begin{tabular}{|c|c|c|c|}
\hline $\begin{array}{l}\text { Question } \\
\text { number }\end{array}$ & Question & Construct & Estimate \\
\hline 1 & $\begin{array}{l}\text { How important is it for a leader to act } \\
\text { morally? }\end{array}$ & Choices & 0.776 \\
\hline 2 & $\begin{array}{l}\text { How important is it for a leader to } \\
\text { manage risk? }\end{array}$ & Choices & 0.377 \\
\hline 3 & $\begin{array}{l}\text { How important is it for a leader to } \\
\text { make moral decisions? }\end{array}$ & Choices & 1.071 \\
\hline 4 & $\begin{array}{l}\text { How important is it for a leader to } \\
\text { communicate and instil company } \\
\text { values in the team? }\end{array}$ & Principles & 0.713 \\
\hline 5 & $\begin{array}{l}\text { How important is it for a leader to } \\
\text { work ethically? }\end{array}$ & Principles & 0.529 \\
\hline 6 & $\begin{array}{l}\text { How important is it for a leader to } \\
\text { ensure that the company operates } \\
\text { ethically? }\end{array}$ & Principles & 0.622 \\
\hline 7 & $\begin{array}{l}\text { How important is it for a leader to } \\
\text { have good thinking skills? }\end{array}$ & Cognitive & 0.614 \\
\hline 8 & $\begin{array}{l}\text { How important is it for a leader to } \\
\text { practise personal reflection? }\end{array}$ & Cognitive & 0.495 \\
\hline 9 & $\begin{array}{l}\text { How important is it for a leader } \\
\text { to learn something new and teach } \\
\text { and/or demonstrate what they } \\
\text { have learnt? }\end{array}$ & Cognitive & 0.710 \\
\hline 10 & $\begin{array}{l}\text { How important is it for a leader to work } \\
\text { with the team, and involve the right } \\
\text { people at the right time? }\end{array}$ & Emotional & 0.509 \\
\hline 11 & $\begin{array}{l}\text { How important is it for a leader to be } \\
\text { motivated and disciplined to achieve } \\
\text { an important goal? }\end{array}$ & Emotional & 0.804 \\
\hline 12 & $\begin{array}{l}\text { How important is it for a leader to } \\
\text { communicate effectively with the team? }\end{array}$ & Emotional & 0.518 \\
\hline 13 & $\begin{array}{l}\text { How important is it for a leader to } \\
\text { consume healthy foods? }\end{array}$ & Physical & 0.969 \\
\hline 14 & $\begin{array}{l}\text { How important is it for a leader to } \\
\text { manage personal and team stress? }\end{array}$ & Physical & 0.386 \\
\hline 15 & $\begin{array}{l}\text { How important is it for a leader to do } \\
\text { some exercise? }\end{array}$ & Physical & 0.955 \\
\hline 16 & $\begin{array}{l}\text { How important is it for leaders to work } \\
\text { toward achieving meaning, purpose and } \\
\text { fulfilment in their life? }\end{array}$ & Spiritual & 0.572 \\
\hline 17 & $\begin{array}{l}\text { How important is it for a leader to lead } \\
\text { and serve a team to achieve company } \\
\text { objectives? }\end{array}$ & Spiritual & 0.736 \\
\hline 18 & $\begin{array}{l}\text { How important is it for a leader to lead } \\
\text { a company to achieve the organisational } \\
\text { dream (vision)? }\end{array}$ & Spiritual & 0.773 \\
\hline
\end{tabular}

Note: All standardised regression weights were statistically significant with a $p$ value of $<0.001$.

The spiritual and principles construct-to-construct correlation is the next strongest with a 0.792 result, defined as having a substantial relationship. The results support the construct operational definitions in which the spiritual construct is defined as a leader's ability to act according to principles; and the principles operational definition being a leader's ability to understand the rules and standards of social, economic, and natural laws. In the context of the conceptual model, the spiritual construct is considered the overall/ primary conduit between the choices and principles constructs. This implies that a leader's ability to choose should be based on principles, and that principles should influence a leaders' decision-making ability or choice.

The principles and emotional construct-to-construct correlation is the third strongest correlation at 0.761 . In the context of the leadership model, the principles construct represents a leader's decision-making foundation; which, in this case, has a strong relationship with a leaders' ability to manage their emotional intelligence, i.e. how they are to perceive, use, understand and manage their emotions.
TABLE 5: Construct-to-construct correlation results.

\begin{tabular}{lcc}
\hline Construct-to-construct correlation & Estimate & $p^{\text {a }}$ \\
\hline Choices $\leftarrow \rightarrow$ Principles & 0.303 & 0.004 \\
Choices $\leftarrow \rightarrow$ Cognitive & 0.115 & 0.247 \\
Choices $\leftarrow \rightarrow$ Emotional & 0.308 & 0.005 \\
Choices $\leftarrow \rightarrow$ Physical & 0.058 & 0.481 \\
Spiritual $\leftarrow \rightarrow$ Choices & 0.097 & 0.295 \\
Principles $\leftarrow \rightarrow$ Cognitive & 0.643 & $* * *$ \\
Principles $\leftarrow \rightarrow$ Emotional & 0.761 & $* * *$ \\
Principles $\leftarrow \rightarrow$ Physical & 0.372 & 0.002 \\
Spiritual $\leftarrow \rightarrow$ Principles & 0.792 & $* * *$ \\
Cognitive $\leftarrow \rightarrow$ Emotional & 0.926 & $* * *$ \\
Cognitive $\leftarrow \rightarrow$ Physical & 0.605 & $* * *$ \\
Spiritual $\leftarrow \rightarrow$ Cognitive & 0.734 & $* * *$ \\
Emotional $\leftarrow \rightarrow$ Physical & 0.455 & $* * *$ \\
Spiritual $\leftarrow \rightarrow$ Emotional & 0.704 & $* * *$ \\
Spiritual $\leftarrow \rightarrow$ Physical & 0.491 & $* * *$ \\
\hline
\end{tabular}

Note: ***Represents a $p$ value of $<0.001$ which is statistically significant.

TABLE 6: Construct correlation strength description.

\begin{tabular}{ll}
\hline Correlation value & Description \\
\hline$<0.20$ & Indifferent, almost negligible relationship \\
$0.20-0.40$ & Definite but slight relationship \\
$0.40-0.70$ & Moderate relationship \\
$0.70-0.90$ & High and substantial relationship \\
$0.90-1.00$ & Very high, rising to perfect relationship \\
\hline
\end{tabular}

Source: Behr, A.L., 1983, Empirical research methods for the human sciences, 2nd edn. Butterworth, Durban

The next strongest construct relationship occurs between the spiritual and mental constructs. In relation to the leadership model, the spiritual construct is defined as a leader's 'ability to understand the rules', which has a strong relationship with that leader's 'ability to think and learn' from the mental construct.

The spiritual and emotional construct-to-construct correlation is the next strongest and defined as having a high and substantial relationship. While the spiritual construct is considered the primary leadership conduit, mainly the fusion between a leader's choices and principles, the emotional construct plays a significant role in a leader's ability to manage emotions during interactions as either a leader or a follower.

The principles and mental relationship are considered moderate. In the context of the leadership model, the result suggests that the principles construct can moderately influence a leader's mental capacity to learn and understand.

The next strongest relationship exists between mental and physical constructs. In relation to the leadership model, a leader's ability to 'think and learn' has a moderate relationship with a leader's ability to manage their physical intelligence, i.e. the ability to manage stress.

The spiritual and physical construct-to-construct relationship is the next strongest with a result of 0.491 . The principles construct represents the 'rules and standards' which has, in the context of the leadership model, the ability to influence the physiological well-being of a leader. 
The next strongest construct-to-construct relationship is the moderate relationship between emotional and physical constructs. The emotional construct represents a leader's ability to manage their emotions. This result suggests that participants perceived that leaders' emotions can moderately influence their stress and overall physiological well-being.

A definite relationship exists between the principles and physical constructs. In the context of the leadership model, the physical dimension of a leader is influenced by the principles construct, that is the physical domain is influenced by natural laws.

The choices and emotional construct-to-construct relationship are considered definite. In this context, leaders can make a choice to manage their emotions.

The next strongest construct-to-construct relationship is the relationship which exists between the choices and principles constructs. The relationship is considered definite, and in the context of the leadership model, the two constructs are opposite one another, implying that they support one another. The results of this study support the relationship.

The results from this study suggest that there is an indifferent or average relationship between the choices and mental constructs. Similar results were found in the construct-toconstruct relationship between the spiritual and choices constructs. The choices and physical construct-to-construct was the lowest relational strength amongst the construct relationships.

The model fit statistics evaluate a model in relation to the fixed parameters applied to postulate the model and the approval or dismissal of the model (Stapleton 1997). Table 7a and Table $7 \mathrm{~b}$ presents a summary of the conceptual model-fit results. The results provide empirical evidence that the conceptual model for leadership skills development is considered a good model fit. Cronbach's alpha coefficient values ranged between 0.604 and 0.803 , which indicate acceptable and satisfactory reliability.

Based on the quantitative results, it seems reasonable to suggest that the leadership constructs within the conceptual model for leadership skills development, as a case in the African FMCG sector, are statistically valid and reliable and are therefore considered appropriate.

Concerning the conceptual model, the results indicate that the mental construct had the most words at $31 \%$, with the emotional construct marginally lower at $29 \%$. The mental and emotional constructs, therefore, represent $60 \%$ of the words described by participants in the interview process regarding the leadership skills required by the FMCG. The principles and spiritual contribute $30 \%$, with $18 \%$ and $12 \%$ respectively. Choices contribute $9 \%$ to the total word count and physical only $1 \%$, with two words used from a total of 321 words.
With the qualitative results and findings, it seems reasonable to suggest that the qualitative phase in this explanatory mixed-methods study explains and elaborates on the initial quantitative results obtained from the quantitative strand. Figure 3 shows the construct distribution results from the qualitative thematic analysis.

Table 8 presents the results of how the qualitative results compliment the initial quantitative results concerning the leadership constructs in the conceptual leadership skills development model.

The six leadership constructs concern how the leadership skills integrate with the conceptual model.

\section{Choices}

Empirical evidence discussed in the quantitative strand notes the choices construct as the second most reliable (0.74) construct and this was supported and explained in the qualitative strand with an overall word count of $9 \%$.

The choices construct concerns the primary construct in the leadership model. In this study, the ability to make choices is described as a process of considering available options, requiring multiple skills, and then choosing an option based on principles (Levin \& Milgrom 2004). As the skill in making good choices develops, decisionmaking may improve decision-making speed, accuracy, and consistency.

TABLE 7a: Model-fit and construct reliability distribution.

\begin{tabular}{lccc}
\hline Model & CMIN/DF & CFI & RMSEA \\
\hline Requirement & $\sim 1: 5$ & $\geq 0.90$ & $<0.100$ \\
Study results & 2.232 & 0.86 & 0.097 \\
Study findings & Good model fit & Acceptable model fit & Good model fit \\
\hline
\end{tabular}

TABLE 7b: Model-fit and construct reliability distribution.

\begin{tabular}{lccc}
\hline Constructs & Cronbach's alpha & Mean & Standard deviation \\
\hline Choices & 0.74 & 6.66 & 0.62 \\
Principles & 0.65 & 6.76 & 0.39 \\
Cognitive & 0.60 & 6.28 & 0.72 \\
Emotional & 0.62 & 6.78 & 0.35 \\
Physical & 0.80 & 5.47 & 1.14 \\
Spiritual & 0.63 & 6.44 & 0.62 \\
\hline
\end{tabular}

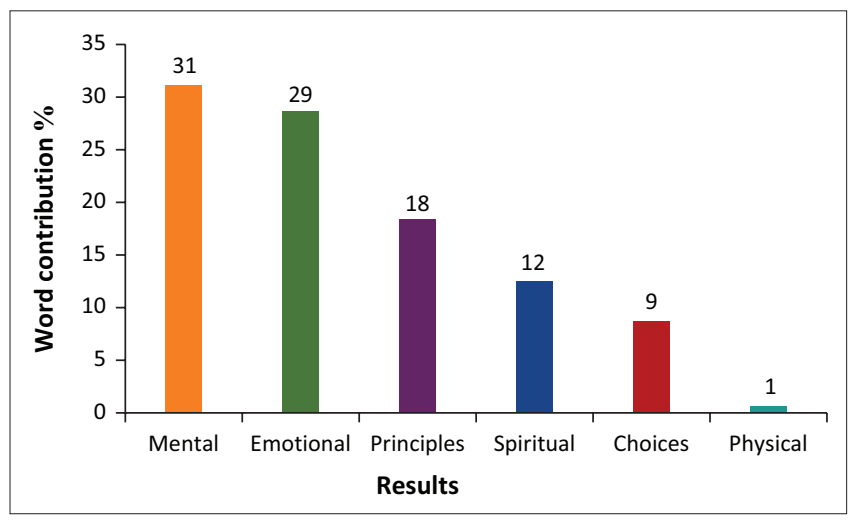

FIGURE 3: Construct distribution results. 
TABLE 8: Summary of results.

\begin{tabular}{llcc}
\hline Super-Cube ${ }^{\oplus}$ Model & Constructs & $\begin{array}{c}\text { Measurement } \\
\text { reliability }\end{array}$ & Qualitative results \\
\hline Model-fit tests: & 1. Choices & 0.74 & $9 \%$ \\
CMIN/DF: 2.232; & 2. Principles & 0.65 & $18 \%$ \\
CFI: 0.86; and RMSEA: & 3. Mental & 0.60 & $31 \%$ \\
0.097 & 4. Emotional & 0.62 & $29 \%$ \\
& 5. Physical & 0.80 & $1 \%$ \\
& 6. Spiritual & 0.63 & $12 \%$ \\
Good model-fit = & Cronbach alpha = construct & Interview: word count \\
accepted as a model & reliable & & \\
\hline
\end{tabular}

\section{Principles}

The empirical results presented in the quantitative strand state that the principles construct is the third most reliable (0.65) and this was confirmed and explained in the qualitative strand with an overall word count of $18 \%$. The principles construct concerns the foundational and guiding principles which relate to the ability to make decisions according to rules or standards (Caldwell et al. 2006).

In this study, principles concern the following:

- Social principles: the skills and abilities to care for other people, putting their needs first, serving others and acting as a servant for the good of another person, i.e. embracing the principles of servanthood leadership.

- Economic principles: the skills and abilities to operate efficiently and effectively in business operations. For example, a business should adhere to economic principles and should make a profit to ensure continuity - to pay employees, suppliers, and fund other businessrelated activities. Importantly, the business must adhere to ethical principles, that is, the rules and standards concerning statutory and regulatory requirements in the context in which they manifest and where the business operates.

- Natural law principles: the skills and abilities to understand and apply the STEM etcetera and natural law, that is gravitational principles.

The understanding of principles will inevitably vary based on personal circumstances, e.g. education and experience; however, improving the understanding and adherence (choices construct) to principles is considered foundational, and intentionally designed as the foundation of the leadership skills development model.

\section{Mental}

Empirical evidence discussed in the quantitative strand notes that the mental construct is the least reliable $(0.60)$, yet was supported and explained in the qualitative strand with the highest word count of $31 \%$. The mental construct represents the skills and ability to solve problems, to plan, to reason, to think, to grasp complex concepts, to learn quickly, learn from experience, and the ability to teach and impart knowledge (Mumford et al. 2017; Prinsloo \& Barrett 2013).
In this article, the mental construct refers to the speed and depth of information processing skills when solving complex problems. Evidence suggests that mental intelligence can improve to provide the knowledge and skills required to perform complex leadership tasks (Mumford et al. 2017).

\section{Emotional}

The empirical results presented in the quantitative strand state that the emotional construct is the fifth most reliable (0.62), yet was explained in the qualitative strand with an overall word count of $29 \%$, the second highest. The emotional construct represents the skills to perceive, use, understand and manage emotions (Mayer et al. 2004).

The emotional construct concerns the skills of self-awareness, self-regulation, motivation, empathy, and social skills. The first three skills are regarded as personal competence, and the last two skills are considered social competence. All five skills determine how relationships are handled and are skills that can be improved (Doe et al. 2015; Heath et al. 2017; Mayer et al. 2004).

\section{Physical}

Empirical evidence discussed in the quantitative strand note that the physical construct is the most reliable $(0.80)$, yet was hardly discussed in the qualitative strand with the lowest overall word count of $1 \%$. The physical construct represents the physiological well-being of a person.

The management of stress, nutrition, and exercise are considered essential aspects of physical well-being (Hattie et al. 2004). Edwards (2006) suggests that regular exercise is associated with significant improvements in physical wellbeing, including aspects of mood, coherence, fortitude, and stress management. Harms et al. (2017) note that stress and leadership are inextricably linked.

\section{Spiritual}

The empirical results presented in the quantitative strand state that the spiritual construct is the fourth most reliable (0.63) and was confirmed and explained in the qualitative strand with an overall word count of $12 \%$. The spiritual construct represents the conduit between the choices and principle constructs and unites the four innate aspects of a person's existence (mind, heart, body and spirit), so that people are intrinsically motivated to achieve important goals (Delaney 2005; Maslow 1972).

The concluding findings from this research indicate that leadership can be developed through a series of events to complete the overall wholeness of a person.

\section{Conclusion}

Africa is huge with an abundance of space to build scalable business-networks. Given the continent's rapidly growing 
population and GDP, Africa is likely to become the most compelling territory for the FMCG industry. The vast unmet needs of Africa and its unfulfilled demand make it a continent ripe for entrepreneurship and innovation at scale.

A smart and original approach to expanding into Africa calls for an innovative business model to unleash talent at scale, as well as find operational solutions to improve business resilience in order to cultivate business leaders of a new nature in the century ahead. It was demonstrated that African FMCG businesses require urgent leadership interventions to improve performance. Importantly, businesses wishing to grow in Africa should have a plan for doing good, while doing well.

This study, therefore, addressed the following two gaps:

1. The need for the unification of traditional and contemporary leadership theories into a more coherent approach.

2. The need for African FMCG businesses to improve leadership capacity to realise potential.

In this study, the aim was to create a leadership skills development model for African FMCG business-networks, to contribute toward developing talent to improve business potential in the African FMCG sector.

The first three research questions and objectives aimed to address the research gap concerning the unification of traditional and contemporary leadership theories into a more coherent approach. The last three questions aimed to address the research gap concerning the need for African FMCG businesses to improve leadership capacity as to realise potential.

In this study, ordinal scales were used to develop response options. Scales were developed to measure, inter alia, the knowledge, beliefs, attitudes, judgements, and sentiments concerning the six constructs in the conceptual leadership skills development model. Terre Blanche and Durrheim (1999) state that a scale measures the intensity, direction and level of potency of the variable being measured. Three questions relating to each of the six constructs were used as the scales.

A thorough review of leadership and leadership development literature resulted in the conceptualisation and operationalisation of a multidimensional conceptual model for leadership skills development comprising six constructs. The key contribution of the conceptual model to leadership skills development was that it effectively incorporates traditional and contemporary leadership theories into a holistic, integrated, coherent and universal approach to leadership skills development.

The leadership skills development model, if adopted by an organisation, will result in a leadership skills development initiative being built on theoretically relevant and empirically validated constructs. This approach should help organisations build the necessary leadership skills to improve leadership capacity and ultimately improve business potential. This perspective should also challenge FMCG (and other) organisations and learning institutions to look toward a new approach to leadership skills development.

\section{Africa implementation}

Offering leadership programmes beyond the FMCG alliance is a fundamental objective. The end-goal is to offer leadership skills development programmes to everyone; that is, from early childhood development, general education, further education, and higher education, i.e. throughout a person's lifecycle, and across the African continent.

\section{Study limitations}

Various concepts of leadership and leadership skills development were discovered during the review of the literature. While the researchers are confident that this study contributed to the creation of a leadership skills development model, it was completed in a leading case study on FMCG in Africa and the results cannot be generalised to other type of organisations in other industries.

\section{Future research}

The opportunity for future research is vast. As leadership is a complex and evolving concept with many variables, opportunities for future research exist, particularly in evaluating the effectiveness of leadership interventions. Based on this study, future research could include, for example, research at an individual level, business level, FMCG Group level, FMCG Alliance level, and an industry and African continent level. Research opportunities exist for longitudinal studies in which subjects are assessed over a period. Opportunities also exist to assess subjects in the various contexts in which they operate, for example, at home, and with their family in the contexts in which people live.

\section{Final remarks}

This study not only presented a leadership skills development model, but also provides a wide range of recommendations on how leadership skills could be developed from an individual, business, group, alliance, and African continent perspective in the FMCG industry. This study should also broaden the debate concerning the evolving concept of leadership and leadership skills development throughout the African FMCG industry. Furthermore, this study should allow leadership skills development institutions to enhance leadership skills development interventions, incrementally, and in a coherent way.

Fast-moving consumer goods businesses in Africa need to work towards developing Africa's talent at scale to unlock the skills that businesses require to promote local economies and create ecosystems throughout the supply chain. The researchers hope to continue research in the field of 
leadership, particularly relating to the effectiveness of leadership interventions.

\section{Acknowledgements Competing interests}

The authors declare that they have no financial or personal relationships that may have inappropriately influenced them in writing this article.

\section{Authors' contributions}

This article forms part of a DBA study at the University of KwaZulu-Natal by C.R.M. with T.G.P. as the supervisor assisting with the conceptual construction of the study and manuscript writing.

\section{Ethical considerations}

This article followed all ethical standards for research with direct contact with human subjects. The Humanities \& Social Sciences Research Ethics Committee at UKZN had granted full approval for this research protocol with reference number: H.S.S./1893/018D.

\section{Funding information}

This research received no specific grant from any funding agency in public, commercial or not-for-profit sectors.

\section{Data availability}

The data that support the findings of this study are available from the corresponding author, T.G.P. upon reasonable request.

\section{Disclaimer}

The views and opinions expressed in this article are those of the authors and do not necessarily reflect the official policy or position of any affiliated agency of the authors.

\section{References}

Antonakis, J. \& Day, D.V., 2018, 'Leadership: Past, present, and future', in J. Antonakis \& D.V. Day (eds.), The nature of leadership, 3rd edn., pp. 3-24, Sage, London.

Avolio, B.J., 2007, 'Promoting more integrative strategies for leadership theory-building', American Psychologist 62(1), 25-33. https://doi.org/10.1037/0003-066X.62.1.25

Bass, B.M., 1990, 'From transactional to transformational leadership: Learning to share the vision', Organizational Dynamics 19(3), 19-37. https://doi. org/10.1016/0090-2616(90)90061-S

Bass, B.M. \& Bass, R., 2008, The Bass handbook of leadership: Theory, research, and managerial applications, 4th edn., Free Press, New York, NY.

Behr, A.L., 1983, Empirical research methods for the human sciences, 2nd edn. Butterworth, Durban.

Bennis, W.G., 1959, 'Leadership theory and administrative behavior: The problem of authority', Administrative Science Quarterly 4(3), 259-301. https://doi. org/10.2307/2390911

Bolden, R., Witzel, M. \& Linacre, N., 2016, Leadership paradoxes: Rethinking leadership for an uncertain world, Routledge, London.

Burns, H., Diamond-Vaught, H. \& Bauman, C., 2015, 'Leadership for sustainability: Theoretical foundations and pedagogical practices that foster change', International Journal of Leadership Studies 9(1), 131-143.

Caldwell, C., Karri, R. \& Vollmar, P., 2006, 'Principal theory and principle theory: Ethical governance from the follower's perspective', Journal of Business Ethics 66(2-3), 207-233. https://doi.org/10.1007/s10551-005-5586-y
Chironga, M., Desvaux, G. \& Leke, A., 2018, Rethinking the African business opportunity, McKinsey and Company, viewed 19 August 2021, from https://www. opportunity, Mckinsey and Company, vilewed 19 August 2021, from https://www. business-opportunity.

Chironga, M., Desvaux, G. \& Leke, A., 2019, Leadership lessons from Africa's trailblazers, McKinsey and Company, viewed 19 August 2021, from https://www. mckinsey.com/featured-insights/middle-east-and-africa/leadership-lessonsfrom-africas-trailblazers.

Cohen, H.B., 2019, 'An inconvenient truth about leadership development', Organizational Dynamics 48(1), 8-15. https://doi.org/10.1016/j.orgdyn.2017.10.002

Conger, J.A., 2010, 'Developing leadership talent: Delivering on the promise of structured programs', in R.F. Silzer \& B.E. Dowell (eds.), Strategy-driven talent management: A leadership imperative, pp. 281-312, Jossey-Bass, San Francisco, CA

Cooper, D.C. \& Emory, C.W., 1995, Business research methods, Irwin, Chicago, IL.

Creswell, J.W. \& Plano Clark, V.L., 2018, Designing and conducting mixed methods research, 3rd edn., pp. 281-310, Sage, London.

Cullen-Lester, K.L., Maupin, C.K. \& Carter, D.R., 2017, 'Incorporating social networks into leadership development: A conceptual model and evaluation of research and practice', The Leadership Quarterly 28(1), 130-152. https://doi.org/10.1016/j. practice', The Leadersh
leaqua.2016.10.005

Dansereau, F., Seitz, S.R., Chiu, C.-Y., Shaughnessy, B. \& Yammarino, F.J., 2013, 'What makes leadership, leadership? Using self-expansion theory to integrate traditional and contemporary approaches', The Leadership Quarterly 24(6), 798-821. https:// doi.org/10.1016/j.leaqua.2013.10.008

Day, D.V. \& Dragoni, L., 2015, 'Leadership development: An outcome-oriented review based on time and levels of analyses', Annual Review of Organizational Psychology and Organizational Behavior 2,133-156. https://doi.org/10.1146/annurevorgpsych-032414-111328

Day, D.V., Fleenor, J.W., Atwater, L.E., Sturm, R.E. \& McKee, R.A., 2014, 'Advances in leader and leadership development: A review of 25 years of research and theory', The Leadership Quarterly 25(1), 63-82. https://doi.org/10.1016/j.leaqua.2013.11.004

Day, D.V., Harrison, M.M. \& Halpin, S.M., 2012, An integrative approach to leader development: Connecting adult development, identity, and expertise, Psychology Press, New York, NY

Day, D.V. \& Sin, H.-P., 2011, 'Longitudinal tests of an integrative model of leader development: Charting and understanding developmental trajectories', The Leadership Quarterly 22(3), 545-560. https://doi.org/10.1016/j.leaqua.2011.04.011

Day, D.V. \& Thornton, A., 2018, 'Leadership development', in J. Antonakis \& D. Day (eds.), The nature of leadership, 3rd edn., pp. 354-380, Sage, London.

De Neve, J.-E., Mikhaylov, S., Dawes, C.T., Christakis, N.A. \& Fowler, J.H., 2013, 'Born to lead? A twin design and genetic association study of leadership role occupancy', The Leadership Quarterly 24(1), 45-60. https://doi.org/10.1016/j. The Leadership

Delaney, C., 2005, 'The spirituality scale: Development and psychometric testing of a holistic instrument to assess the human spiritual dimension', Journal of Holistic Nursing 23(1), 1-23. https://doi.org/10.1177/0898010105276180

Doe, R., Ndinguri, E. \& Phipps, S.T.A., 2015, 'Emotional intelligence: The link to success and failure of leadership', Academy of Educational Leadership Journal 19(3), 105116.

Drucker, P.F., 1995, Managing in a time of great change, Truman Talley Books/Dutton, New York, NY.

Eberly, M.B., Johnson, M.D., Hernandez, M. \& Avolio, B.J., 2013, 'An integrative process model of leadership: Examining loci, mechanisms, and event cycles', American Psychologist 68(6), 427-443. https://doi.org/10.1037/a0032244

Edwards, S.D., 2006, 'Physical exercise and psychological well-being', South African Journal of Psychology 36(2), 357-373. https://doi.org/10.1177/00812463060 3600209

Edwards, S.D., 2012, 'Standardization of a spirituality scale with a South African sample', Journal of Psychology in Africa 22(44), 649-653. https://doi.org/10.1080 sample', Journal of Psycholo

Euromonitor International, 2018, Shifting market frontiers megatrend: Africa rising, viewed 19 August 2021, from https://go.euromonitor.com/strategy-briefingmegatrends-2018-africa-rising.html.

Fiedler, F.E., 1971, Leadership, General Learning Press, New York, NY.

Field, A., 2009, Discovering statistics using SPSS, 3rd edn., Sage, London.

Foti, R.J. \& Hauenstein, N.M.A., 2007, 'Pattern and variable approaches in leadership emergence and effectiveness', Journal of Applied Psychology 92(2), 347-355. https://doi.org/10.1037/0021-9010.92.2.347

Groenland, E. \& Dana, L.P., 2019, Qualitative methodologies and data collection methods: Toward increased rigour in management research, World Scientific Publishing, Singapore.

Gully, S. \& Chen, G., 2010, 'Individual differences, attribute-treatment interactions, and training outcomes', in S.W.J. Kozlowski \& E. Salas (eds.), Learning, training, and development organizations, pp. 3-64, Routledge, New York, NY.

Hackman, J.R. \& Wageman, R., 2007, 'Asking the right questions about leadership', American Psychologist 62(1), 43-47. https://doi.org/10.1037/0003-066X.62.1.43

Harms, P.D., Credé, M., Tynan, M., Leon, M. \& Jeung, W., 2017, 'Leadership and stress: A meta-analytic review', The Leadership Quarterly 28(1), 178-194. https://doi. org/10.1016/j.leaqua.2016.10.006

Hattie, J.A., Myers, J.E. \& Sweeney, T.J., 2004, 'A factor structure of wellness: Theory, assessment, analysis, and practice', Journal of Counseling and Development 82(3), 354-364. https://doi.org/10.1002/j.1556-6678.2004.tb00321.x 
Heath, K., Martin, L. \& Shahisaman, L., 2017, 'Global leadership competence: The intelligence quotient of a modern leader', Journal of Leadership Education 16(3), 134-145. https://doi.org/10.12806/V16/13/T3

Hollander, E.P., 2009, Inclusive leadership: The essential leader-follower relationship, Routledge, New York, NY.

Hollenbeck, G.P., McCall, M.W.J. \& Silzer, R.F., 2006, 'Leadership competency models', The Leadership Quarterly 17(4), 398-413. https://doi.org/10.1016/j.leaqua. 2006.04.003

Holt, S., Hall, A. \& Gilley, A., 2018, 'Essential components of leadership development programs', Journal of Managerial Issues 30(2), 214-229.

Illeris, K., 2018, 'An overview of the history of learning theory', European Journal of Education 53(1), 86-101. https://doi.org/10.1111/ejed.12265

Jacobs, E. \& Mafini, C., 2019, 'Transactional leadership, supply chain quality and business performance in the fast-moving consumer goods industry', Journal of Transport and Supply Chain Management 13(1), 13. https://doi.org/10.4102/ jtscm.v13i0.442

Johns, G., 2006, 'The essential impact of context on organizational behavior', Academy of Management Review 31(2), 386-408. https://doi.org/10.5465/amr.2006. 20208687

Kegan, R. \& Lahey, L.L., 2016, An everyone culture: Becoming a deliberately development organization, Harvard Business Review Press, Boston, MA.

Kim, J. \& McLean, G.N., 2015, 'An integrative framework for global leadership competency: Levels and dimensions', Human Resource Development International 18(3), 235-258. https://doi.org/10.1080/13678868.2014.1003721

Landis, E.A., Hill, D. \& Harvey, M.R., 2014, 'A synthesis of leadership theories and styles', Journal of Management Policy and Practice 15(2), 97-100.

Leke, A., Chironga, M. \& Desvaux, G., 2018, Africa's overlooked business revolution McKinsey and Company, viewed 19 August 2021, from https://www.mckinsey. com/featured-insights/middle-east-and-africa/africas-overlooked-businessrevolution.

Levin, J. \& Milgrom, P., 2004, Introduction to choice theory, pp. 1-25, viewed 19 August 2021, from https://web.stanford.edu/ jdlevin/Econ\%20202/Choice\%20 Theory.pdf.

Lord, R.G. \& Hall, R., 1992, 'Contemporary views of leadership and individual differences', The Leadership Quarterly 3(2), 137-157. https://doi.org/10.1016/ 1048-9843(92)90030-J

Maslow, A.H., 1972, The further reaches of human nature, The Viking Press, New York, NY.

Mayer, J.D., Salovey, P. and Caruso, D.R., 2004, 'Emotional intelligence: Theory, findings, and implications', Psychological Inquiry 15(4), 197-215. https://doi. org/10.1207/s15327965pli1503_02

McCauley, C.D., Van Velsor, E. \& Ruderman, M.N., 2010, 'Introduction: Our view of leadership development', in E. Van Velsor, C.D. McCauley \& M.N. Ruderman (eds.), The Center for Creative Leadership handbook of leadership development 3 rd edn., pp. 1-26, Jossey-Bass, San Francisco, CA.

McMillan, J.H. \& Schumacher, S., 2010, Research in education: Evidence-based inquiry, MyEducationLab series, Pearson, London, United Kingdom.
Morgan, W.J. \& Guilherme, A., 2012, 'I and thou: The educational lessons of Martin Buber's dialogue with the conflicts of his times', Educational Philosophy and Buber's dialogue with the conflicts of his times', Educational Philosophy
Theory 44(9), 979-996. https://doi.org/10.1111/j.1469-5812.2010.00681.x

Mumford, M.D., Todd, E.M., Higgs, C. \& McIntosh, T., 2017, 'Cognitive skills and leadership performance: The nine critical skills', The Leadership Quarterly 28(1), 24-39. https://doi.org/10.1016/j.leaqua.2016.10.012

Mumford, T.V., Campion, M.A. \& Morgeson, F.P., 2007, 'The leadership skills strataplex: Leadership skill requirements across organizational levels', The Leadership Quarterly 18(2), 154-166. https://doi.org/10.1016/j.leaqua.2007.01.005

Prinsloo, M. \& Barrett, P., 2013, Cognition: Theory, measurement, implications, pp. $1-27$, viewed 19 August 2021, from http://integralleadershipreview.com/9270cognition-theory-measurement-implications/.

Saunders, M.N.K. \& Tosey, P., 2012, The layers of research design. Rapport (Winter 2012/2013), pp. 58-59, viewed 19 August 2021, from https://www.csd.uoc. gr/ hy109/resources/layers.pdf.

Shenton, A.K., 2004, 'Strategies for ensuring trustworthiness in qualitative research projects', Education for Information 22(2), 63-75. https://doi.org/10.3233/EFIprojects', Educc

Shrivastava, S., Selvarajah, C., Meyer, D. \& Dorasamy, N., 2014, 'Exploring excellence in leadership perceptions amongst South African managers', Human Resource Development International 17(1), 47-66. https://doi.org/10.1080/13678868.201 Developm
3.857510

Stapleton, C.D., 1997, 'Basic concepts and procedures of confirmatory factor analysis', Paper presented at the Annual Meeting of the Southwest Educational Research Association, January 24, 1997, Austin, TX, pp. 1-15.

Swaniker, F., 2018, Talent and technology in Africa today, McKinsey and Company, viewed 19 August 2021, from https://www.mckinsey.com/featured-insights/ middle-east-and-africa/talent-and-technology-in-africa-today.

Tashakkori, A. \& Teddlie, C., 2003, Handbook of mixed methods in social \& behaviora research, Sage, Thousand Oaks, CA.

Terre Blanche, M.J. \& Durrheim, K., 1999, Research in practice: Applied methods for the social sciences, University of Cape Town Press, Cape Town.

Terre Blanche, M.J., Durrheim, K. \& Painter, D., 2006, Research in practice: Applied methods for the social sciences, 2nd edn., UCT Press, Cape Town.

Vicere, A.A. \& Fulmer, R.M., 1998, Leadership by design: How benchmark companies sustain success through investment in continuous learning, Harvard Business School Press, Boston, MA.

Wilson, S. \& McCalman, J., 2017, 'Re-imagining ethical leadership as leadership for the greater good', European Management Journal 35(2), 151-154. https://doi. org/10.1016/j.emj.2016.06.001

Yammarino, F.J., 2017, 'Leadership', in J. Stein (ed.), Reference module in neuroscience and biobehavioral psychology, pp. 1-12, Elsevier, Oxford.

Yukl, G., 2012, 'Effective leadership behavior: What we know and what questions need more attention', Academy of Management Perspectives 26(4), 66-85. https://doi.org/10.5465/amp.2012.0088

Zaccaro, S.J., LaPort, K. \& José, I., 2012, 'The attributes of successful leaders: A performance requirements approach', in M.G. Rumsey (ed.), The Oxford handbook of leadership, pp. 11-36, Oxford University Press, New York, NY. 